\title{
George Steiner o sobre el discurso ético en la crítica literaria
}

\section{George Steiner or on the Ethical Discourse in Literary Criticism}

\author{
Felipe González Alcázar \\ Universidad Complutense de Madrid \\ claudiofelipegonzalez@filol.ucm.es \\ ORCID iD: http://orcid.org/0000-0003-0992-6275
}

\section{RESUMEN}

La crítica literaria plantea un tipo de discurso especial. Además, la teoría y la crítica literarias del siglo XX han tenido diversas tradiciones en el mundo occidental; en la cultura anglosajona ha perdurado la idea de que el crítico y, por consiguiente, el pensamiento literario, debe estar regido por un modelo y un propósito éticos. La propuesta de George Steiner, debido a su gran popularidad y su capacidad para extenderse más allá de la recepción académica, y enfrentada tanto al formalismo crítico como a la deconstrucción, se convierte en un ejemplo de crítica ética, personal, culta e ingeniosamente polémica.

Palabras Clave: teoría de la literatura; crítica literaria; crítica ética; George Steiner.

\begin{abstract}
Literary criticism presents a sort of peculiar discourse. Besides, during $\mathrm{XX}^{\text {th }}$ century, theory of literature and literary criticism developed, in Occidental area, different traditions. In Anglo-Saxon culture remained a main concept: the critic, consequently, literary thinking, must be rule by an ethical pattern and aim. George Steiner's proposal, on account of his great popularity and ability to spread beyond academic reception, and facing not only critical formalism but also deconstruction, turns into an excellent example of ethical, personal, highbrow and wittily controversial criticism.
\end{abstract}

Key words: Theory of literature; Literary criticism; Ethical criticism; George Steiner.

\section{HACIA UNA CRÍTICA ÉTICA}

La crítica literaria, siguiendo a Barthes, es sencillamente un discurso sobre otro discurso, con todas las implicaciones y consecuencias que ello tiene. Algo 
de ingenuidad y adanismo, presentes en ciertos métodos, han contribuido a hacer creer a sus defensores que las cuestiones que plantean les incumben a ellos en tanto su manera de acercarse a la literatura significa más que otras. A menudo olvidan cuánto se deriva de la naturaleza y de las propiedades de esa misma literatura que en ocasiones solo aparece arrumbada, a lo lejos, entrevista detrás de otros debates o lenguajes artísticos. Cabe plantearse si los paradigmas teóricos, las diversas escuelas críticas, o solamente enfoques, presentados didácticamente en forma historiada y sucesiva, han de actuar de manera cainita entre sí o más bien colaboran con una idea clara de cuál ha de ser su objetivo último ${ }^{1}$. Permítaseme ejemplificar con un breve inédito de Ortega ${ }^{2}$ en que el filósofo propone cuestionarse el ser de la literatura, esta compleja dependencia entre fines y medios, y sus consecuencias:

Con razón o sin ella, creemos poseer una noción aproximadamente clara de qué es ciencia, de qué es religión. En cambio, no gozamos ni de lejos de claridad pareja respecto a qué es literatura. La cosa es de alguna importancia sobre todo para el francés, cuya vida personal y colectiva se ha nutrido más que ninguna otra de Literatura. Es un poco escandaloso que no se haya intentado con urgencia responder a la pregunta vital y nada "retórica" de por qué el hombre hace literatura. Y, sin embargo, sólo ella puede dar nueva sangre vivaz a la historia literaria,

${ }^{1}$ Parece que la solución a una aparente dislocación de propuestas, a la melancolía de dejar atrás aquello que nos parece que sirve volviendo a aparecer después, - $-\mathrm{y}$ los ejemplos son inagotables en los entresijos de nuestras argumentaciones como en aquella máxima ciceroniana: difficile est longum subito deponere amorem - , a cambio de afrontar lo novedoso por imperativo de los tiempos y por asimilación con otros productos efímeros, enmascarado de propiedad cerrada como un desfile de escuelas, de fases artísticas o creativas, o de aplicaciones que son superadas en un constante upgrade, todo ello, ha culminado en una especie de eclecticismo de honda raigambre educativa (González Alcázar 2005: 335-349). Eclecticismo, por lo demás, necesario para domesticar la viveza y la virulencia de los planteamientos postmodernos, o solamente postformalistas, y regido por una razón de sentido común y utilidad lógica para la que se han gastado muchas energías huyendo de evidencias que han estado siempre ahí delante. Véanse, por ejemplo, Compagnon (2015), Schaeffer (2013), o los avisos ya lejanos de los primeros años ochenta que ahora se redescubren como antecedentes al calor del testimonial arrepentimiento filosófico de Ferraris (2013), pero mejor armados para la teoría y la crítica literarias que este último. Tuve ocasión de referirme a ello anteriormente (González Alcázar 2008: 36-42).

2 Se trata de parte de las hojas 6 y 7 del manuscrito B-145/2, «[Et quand au pacifisme = En cuanto al pacifismo...]», custodiado en el Archivo de la Fundación Ortega-Marañón, a quien doy las gracias por su permiso para la primera edición de este inédito. El documento lleva la fecha de 27 de abril de 1938, y consiste en una agrupación miscelánea con embriones de artículos que Ortega se proponía escribir para ofrecer a la prensa francesa durante los durísimos meses del exilio parisino. Este breve texto lleva el número VII y por título «¿Qué es la literatura?». Me he limitado a editar el texto manuscrito sin corrección ortográfica ni gramatical alguna, y respetando las cursivas del autor. Hay ideas e incluso expresiones literales en la lección IV del curso El hombre y la gente de 1939-1940. 
a la crítica y a... muchas otras cosas. Se trataría, pues, en este ensayo de no eludir aquella pregunta sino de responder frente a frente.

Implícita en esta propuesta, la noción de literatura se asoma como un asidero necesario tras el cual se vislumbran afirmaciones que, pese a su perennidad, nunca son totalmente satisfechas: todas las que se derivan de la conexión entre medios y fines, así como la necesidad de que la crítica en su función ancilar nos devuelva una y otra vez al punto de partida. En palabras de Ortega, saber qué es literatura es inseparable de saber por qué se hace literatura. Así pues, también este argumento tiene su reverso ya que los problemas de la crítica son problemas de la literatura, y esto remite a una circularidad muy aprovechada por las corrientes postmodernas ${ }^{3}$. Las respuestas a esas incitaciones constituyen la labor del crítico ${ }^{4}$ en su búsqueda de un modelo de argumentación. El planteamiento actual exige del crítico delimitar y explicar a la vez su propia crítica, a despecho de gran parte de los scholars anteriores que se limitaban a ejercer su labor de intérprete, mediador o filólogo. En la supuesta ausencia de normas, preceptos o formalizaciones a priori, ya la crítica decimonónica aprendió a situarse entre las ciencias humanas con ayuda de los recursos histórico y positivista para su mediación. Como todo acto sometido a la evaluación de un sujeto pensante, precisaba de un método que fuera verificable por la razón y, después, por otro tipo de procedimientos ya que el material que trabajaba era altamente sensible: sentidos, imaginación, estímulos estéticos o valores morales, ideológicos ${ }^{5} \ldots$

3 Véase en Schaeffer (2013: 46-51) la discusión sobre el dilema a que conduce esa circularidad.

${ }^{4}$ Debo dar por sobreentendidos los imprecisos límites de los conceptos técnicos. No obstante, pese a que la tradición anglosajona de recurrir a criticism para todo aquel estudio literario previo a la presencia en su espacio académico de nuestra theory of literature (aunque Jonathan Culler sancionara que bastaba con el término theory como modelo de discurso teórico sobre cualquier conocimiento) sea confusa para nuestro ámbito europeo no anglosajón (señal implícita de que para él consistía en un método discursivo o en un género, quizás, de la filosofía), a despecho de una más operativa división ofertada por René Wellek - lo teórico descriptivo frente a lo crítico evaluativo-, en este trabajo voy a manejarme entre ambos conceptos con calculada ambigüedad.

${ }_{5}^{5}$ Así pues, y como vengo sosteniendo, si se considera a la literatura como discursos que no solo comunican sino que además imponen ideología o quizás consignas, la crítica ha de plantearse su función hacia el reconocimiento de textos que operan imponiendo modelos de mundo o enfrentándose a esas imposiciones (téticos y atéticos). La consecuencia de la discursivización (paralela a la textualización), ya se sabe, ha sido superar el concepto de intertextualidad tal y como fue formulado por Julia Kristeva, en su aclaración a Bajtín, y extender el concepto de literatura a otros discursos (Asensi 2011: 7-91). Se sobreentiende que también la teoría y la crítica han hecho el mismo viaje, pero a diferencia de la literatura, que puede impregnar todos los discursos y salir airosa (tan viejo como que Homero siempre triunfa sobre Platón), aquellas no pueden seguir a su rebufo y se hunden. 
El razonamiento argumentativo del discurso crítico provee de unos medios de verificación que a veces pasan por verdaderos actos de fe, basados en el prestigio del crítico y en el material que maneja, favoreciendo la tradición canónica de los Great Books. En otras ocasiones, las argumentaciones son tan provisionales que ni siquiera hace falta esperar a que el tiempo las derrote . $^{6}$ Allí donde el discurso de la crítica frena o se ve atrapado en un sistema que conduce al solipsismo, el razonamiento busca su camino buscando un hermanamiento con otras disciplinas, en nuestro caso humanísticas o al menos humanas, fundadas en la interdisciplinariedad como modo de esquivar la levedad de los instrumentos que han de ayudar a revelar los enigmas del texto ${ }^{7}$. Tal levedad confiere a la crítica literaria un modo de argumentación propio de un discurso declarativo y abierto, difícilmente sistematizado o sistematizado $a$ posteriori, al que a menudo faltan propiedades como coherencia, niveles de referencia, virtudes como la pertinencia, o resultan escasamente inteligibles ${ }^{8}$. A veces literatura en segundo grado, el patrón discursivo de la crítica queda ahogado bien por una construcción retórica bien por su integración en el ámbito de la interacción social a través de su transformación en ideología 9 .

Los métodos formales creyeron que podrían superar esta contingencia sustentándose en un inmanentismo que cerraba su centralidad sobre el texto literario, con ayuda de la lingüística saussureana y de la tradición formalizadora poético-retórica que se empeñaron en ocultar. Los avatares posteriores de la lingüística acabarían por integrarse de manera natural en los estudios literarios. Las consecuencias de la inflación terminológica, y de la dificultad de su entendimiento por los no iniciados, haciéndose pasar por formalizaciones lógico-matemáticas — quizás convenga tener presente el affaire Sokal no solo como

${ }^{6}$ Los testimonios son muy numerosos pero me permito citar una frase de un artículo reciente de Enrique Vila-Matas, plenas de fina ironía: «¿O acaso no nos fascinan las teorías literarias porque a veces son verdaderas, pero sólo lo son en parte, y por tanto los adversarios intelectuales de las mismas no se equivocan?», El País, 12 de mayo de 2015, p. 24.

7 «El crítico, por consiguiente, opera sobre muy leves fundamentos teóricos. Tiene que ser lo suficientemente pragmático como para aceptar por fe lo que no está en condiciones de demostrar ni de percibir: que para él ha de existir diferencia entre un objeto-en-la-experiencia y su experiencia de un objeto, aunque la epistemología "crítica" tienda a reducir lo primero a lo segundo» (Krieger 1992: 34-35).

8 Véase Cioranescu (2014: 49-72), en un modélico artículo sobre la dificultad de acercarse a la literatura desde la lingüística, y su consecuencia para analizar el discurso crítico, dependiente a su vez del literario.

9 No voy a insistir en un estudio técnico del discurso crítico, sería otro trabajo, solamente me permito apuntar sobre algunos de los condicionantes de su naturaleza, constatando la riqueza multidisciplinar del análisis actual del discurso, menos dirigido por la pragmática tradicional y más volcado hacia la interpretación del sentido por la vía cognitiva y a la dimensión sociopolítica que a la semántica discursiva. Véanse las aclaraciones de van Dijk y de Beaugrande (2000: 21-106). 
munición antipostmoderna - han sido muy estudiadas y achacadas principalmente al modelo estructural y sus derivados ${ }^{10}$, de los que hoy solo parecen subsistir la pragmática y la narratología. Previa a esta eclosión, pues ni el formalismo ruso ni el estructuralismo semiótico checo se conocieron en Europa occidental con profundidad hasta fines de los años cincuenta, la tradición crítica era en su mayor parte ametódica ${ }^{11}$ pero también, a su manera, inmanente:

Lo que viene hoy a la mente, como materialización central de ese proyecto, es la crítica estructural, ya tenga por objeto los temas (exploraciones del imaginario, de las obsesiones conscientes o inconscientes) o el propio sistema expresivo (procedimientos narrativos, figuras, estilo). Pero la crítica histórica y filológica, tal como se practica desde el siglo XIX, es igualmente fiel al proyecto inmanentista, puesto que el sentido de cada texto no puede establecerse sino en relación a su contexto particular, y la tarea del filólogo consiste en explicar ese sentido sin emitir juicio alguno al respecto (Todorov 2005: 15).

La preocupación por las consecuencias últimas del formalismo estructuralista y sus derivados, quizás en su momento - y junto al irracionalismo - una reacción para liberarse del peso tanto imaginativo cuanto, en exceso, figural del Simbolismo poético (Rancière 2009: 201), ya fue causa de batalla sostenida por la crítica tradicional ${ }^{12}$ y por la crítica marxista. En el ámbito al que pertenece George Steiner (París 1929), educado universitariamente en Chicago durante los años en que la escuela aristotélica pretendía enfrentarse a los new critics estadounidenses, la crítica literaria común se consideraba heredera del tradicional liberal humanism. Ya en el siglo XX, en Cambridge, la evolución de estos modelos de lectura, siempre dentro de la esfera de la educación y del conocimiento, fue renovada, es sabido, por Richards, Epson y Leavis, a los que se unió después T. S. Eliot. Este patrón ${ }^{13}$, alejado de aquel Idealismo estético alemán que influyó tanto en la construcción de nuestra filología moderna y en la estilística hispana, ha perdurado hasta hoy en la defensa del subjetivismo crítico, en la utilidad del conocimiento para la vida de los grandes escritores,

10 Baste, entre muchos, remitir a dos artículos de García Berrio (2008a: 412-432 y 2008b: 641-678), uno ya en 1977, tras el último Barthes, y el segundo de 1984, en medio de la marea deconstructivista.

11 Todorov reconocía en 1984 junto a Paul Bénichou que era, de común y al menos, parcialmente metódica, y siempre necesitada de la combinación de métodos diversos (Todorov 2005: 150-156).

12 Recuérdense la cantidad de objeciones, plenas de sentido común, a la tendencia al vacío del renovado concepto de forma y a la separación progresiva, hasta la independización, de la crítica sobre la literatura o al intento, no negado, por Barthes de convertirla a su vez en literatura, en aquel famoso coloquio de 1966, coetáneo del nacimiento de la nouvelle critique, compilado por Poulet (1969).

${ }_{13}$ No voy a insistir en una bibliografía abundantísima. Me arriesgaré a señalar, a modo de resumen, esta deriva bajo la atenta pero adversa mirada de Terry Eagleton (1999 y 2005). 
en la propagación de valores humanos universales a través de los textos en forma de paráfrasis, en el rechazo a la teoría ${ }^{14}$. No obstante, también abogó por el necesario aislamiento del texto frente a la historia o el contexto, exacerbado después en las fallacies de la Nueva Crítica, anudando en torno a la lectura un respeto reverencial ${ }^{15}$. Esta mixtura de actitud científica y de aura de religiosidad en Steiner, quizás inspirado en Blackmur, inevitablemente conducía a fomentar un crítico sobresaliente por sus actitudes y conocimientos, un altísimo profesional de la cultura. Al pasar al otro lado del Atlántico, la interpretación estetizante, no necesariamente clasista o sureña, aunque en ello incidirán algunos en tanto defensa de una serie de valores morales (Eagleton 2005: 153 y ss.), se disuelve en el preludio de los estudios culturales, en la formación de una teoría cultural novedosa y en una teoría moral, defendidas por los deconstructivistas que, lejos de confrontar sus principios con otros anteriores, dieron paso al ambivalente juego de la imposible comunicación satisfactoria junto al anhelo necesario del Otro como exigencia de esa comunicación. Fue el preludio de la controversia estructuralista y postestructuralista, vivida en los departamentos de Inglés anglosajones como una verdadera crisis, o incluso civil war (Barry 1995: 32).

La recepción de los trabajos de Steiner, sobre todo de los presupuestos teológicos, desenfocada en gran parte por su capacidad para la atracción de públicos cultos pero no especializados, ha sido inmensa. La variedad de sus intereses, muchos de los cuales voy a dejar aquí deliberadamente al margen, su voluntad de situarse bajo todos los focos y su afán de polemista, encierran también cierta petulancia atractiva y particular ${ }^{16}$. Intentar hacerse presente, con

${ }^{14}$ Escribe Steiner (2011: 15-16): «Siempre he desconfiado de la teoría a la hora de resolver mis asuntos emocionales, intelectuales y profesionales. En la medida de mis posibilidades, encuentro al concepto de teoría en las ciencias exactas y, hasta cierto punto, en las ciencias aplicadas. [...] Las humanidades no son susceptibles ni de experimentos cruciales ni de verificación (salvo en un plano material, documental). Nuestras respuestas a ellas son pura intuición [...] Los juegos deconstruccionistas o posmodernos, la imposición de modelos metamatemáticos en el estudio de la historia y de la sociedad (teniendo en cuenta lo pretenciosamente ingenuas que a menudo son las matemáticas) condicionan en gran medida el clima en que se desarrollan los trabajos académico-críticos. Los teóricos en el poder consideran mi propia obra, si es que la consideran de algún modo, como impresionismo arcaico».

${ }_{15}$ Acerca de la especial función que el New Criticism atribuye a la lectura, al crítico mediador en su autoridad trasmisora, a la diferencia entre poesía y prosa, y a las reacciones que suscitó en el mundo académico estadounidense la presencia de las ideas de Poulet y sus discípulos desde los años 50 (sobre todos, Hillis-Miller, ya que no parece oportuno situar aquí a De Man), remito a la recensión de Nora Catelli (1991: 21-26), inspirada por Lentricchia (1990).

16 Júzguese, al contrario, una cierta búsqueda de equilibrio en esta summa curricular de Steiner (2011: 191-192): «Puede que ya no sea legítimo para ningún individuo publicar sobre literatura griega antigua y ajedrez, sobre filosofía y novela rusa, sobre lingüística y 
una muy real presencia en casi todos los debates augurales, crepusculares y cenitales del pensamiento cultural y literario, en donde los límites con otros saberes y ciencias suelen ser tan imprecisos y ambivalentes, no acostumbra a dejar indiferente ni a la recepción académica ni a la mediática ${ }^{17}$. Tampoco lo hace la contundencia de sus expresiones traducidas a tantas lenguas, con la rabia subsiguiente de aquellos que se han sentido atacados por la acusación de traición de los intelectuales a la cultura occidental. Ni que decir tiene que su libro más conocido y polémico, Presencias reales ${ }^{18}$, ha sido tomado como excusa para disputas religiosas o políticas. Así, tanto sus apetencias de una metafísica trascendente cuanto sus frecuentes imágenes apocalípticas se han discutido en torno a capilaridades entre la fe y la política en el mundo académico estadounidense (y de ahí, al resto): la cuestión judía, la traición a esas raíces por el cristianismo, la solución eucarística al problema del significado, la opción izquierdista o derechista de unas opiniones en principio demoledoras para ambas orientaciones... ${ }^{19}$ En el ámbito de la teoría y la crítica literarias, si se deja al margen la influencia de sus ensayos sobre o dentro del comparatismo estricto $^{20}$, era inevitable una controversia defensiva ya fuera argumentando con-

estética; quizá tampoco sea aconsejable ocupar puestos universitarios y al mismo tiempo escribir ficción y más de 150 críticas de libros para el New Yorker, [...] Para los menos dotados, pueden ser demoledores. A medida que se acerca el final, sé que mi multitudinaria soledad, que la ausencia de una escuela o movimiento surgido de mi obra y que la suma de sus imperfecciones son, en notable medida, sólo responsabilidad mía. La apropiación, el expolio de que han sido objeto mis escritos y enseñanzas por parte de otros, el desprecio flagrante de quienes han encontrado ofensivas su proyección pública y su diversidad, puede, en virtud de una irónica paradoja, haber sido su auténtica recompensa. Pero la tristeza, la tristitia, esa entumecedora palabra latina, está ahí».

17 Véase una pequeña muestra de su recepción polivalente en el también grafómano Eagleton (2012: 225): «Es posible que Steiner sea uno de los últimos de una gran raza de humanistas europeos, pero es además un artista de la intelectualidad con un astuto sentido de la teatralidad, un exótico mago que saca autor tras autor de la galera aparentemente sin fondo de su erudición».

${ }^{18}$ El éxito del libro reclama periódicamente reediciones en número sin duda sorprendentes en un texto, en principio, para un público lector más restringido. Véase la recientísima edición en Siruela, 2017, con prefacio inacabado de Claudio Guillén, comenzado a escribir en 2007, donde resalta la tarea fundamental de Presencias reales como búsqueda de un «estatus ontológico» de las artes.

19 Puede verse con detalle en los volúmenes conjuntos dedicados a su obra (Scott, Nathan y Sharp 1994 y Dauzat 2003) que se citan en la bibliografía. También en las respuestas, no siempre mesuradas, de sus escritos.

${ }^{20}$ La literatura comparada adquiere una retraída función y escasa utilidad sin una estricta voluntad de aprehender los principios y métodos teóricos necesarios para plantearlos en un estudio aplicado. La extensión de los límites del concepto de literatura en una intertextualidad porosa pero sutilmente extraliteraria hasta desvalorizarlo por completo, junto a la falta de rigor en el uso de principios críticos, convierte en una suerte de comparatismo sobrevenido a casi toda la crítica ideológica, sistémica y de estudios culturales. Enfrentarse 
fusión de conceptos (Jauss 2012) o escasa originalidad y exceso de divulgación hasta una consecutiva «domesticación de la filología» (García Berrio 2009a y 2009b); pero también, debido a un éxito capaz de llegar a un público muy numeroso y a una amplia acogida, no exenta de matices ${ }^{21}$, dentro de la lucha contra las corrientes disolventes del significado y de la responsabilidad en la afanosa labor explicativa y mediadora.

Las ideas de Steiner sobre la crítica y sus modos habían aparecido muy pronto y se han mantenido con una persistencia y circularidad insistentes, firmes, como muestra de una rara madurez. La pauta fue el encuentro del crítico directamente con el texto en una suerte de hermenéutica desvalida, imposible de sostener la mirada cara a cara con la gran literatura de obras maestras. La desvalorización de la cultura por el poder y su manipulación, ya fuera impulsada por una democratización de la tradición liberal del desinterés estético, su militancia contra la Nueva Crítica o a causa de la penetración de un marxismo mitigado, y por ello disfrazado, bajo una cierta aceptación del espacio occidental de convivencia que él percibía en los escritos de la escuela de Frankfurt ${ }^{22}$, le impulsaron a un hondo pero declinante compromiso:

a la prueba de validez crítica en diferentes literaturas y salir airoso no es sencillo, «de ahí que algunos de los mejores teóricos de nuestro siglo hayan sido grandes comparatistas» (Wahnón 2008: 262). Algo de esto hay en el controvertido juicio de Steiner en su especialidad académica — dejando aparte impagables esfuerzos como Antígonas (1996) y sus seminales trabajos sobre el lenguaje y los problemas de la traducción (1982 y 2001d), o la desaparición de la tragedia clásica y clasicista $(2001 \mathrm{c}$ ) - , a quien se prefiere ver como un crítico cultural (1988b, 2001c y 2009), eso sí, de algo desusado y elitista llamado high culture. Aun asumiendo una confesada fobia a la teoría, su reflexión sobre principios comparatistas parece a simple vista, si no tenemos en cuenta la práctica del análisis comparado, cuanto menos átona. Léanse, por ejemplo, «¿Qué es literatura comparada?» (1997: 121-145), discurso inaugural en Oxford en 1994, o la breve - y aparentemente muy leve- contribución, «Roncevaux», al libro conjunto editado por Werner Sollors, en 1993 (The return of thematic criticism. Cambridge-London: Harvard University Press, pp. 299-300). No obstante, antitéticamente, también ha resultado proverbial su capacidad de apuntar sobre problemas y controversias en cuestiones del comparatismo, como su sencilla pero certera afirmación sobre la naturaleza temática de la literatura en el citado «Roncesvaux».

${ }^{21}$ Por ejemplo, Wahnón (2008: 260) ajusta el sentido de la Ciudad Secundaria que se describe en Presencias reales, donde conviven las producciones de la crítica, no como una muestra del desaforamiento teórico-crítico, de su arrogante intención de existir sin, o sobre, la literatura, sino del verdadero valor en sí de esos grandes ensayos. Frente a lo parasitario, lo que se quiso «poner de relieve al subrayar el carácter primario de la literatura respecto de todos sus metatextos (filosóficos, críticos, teóricos o comparatistas) fue que éstos no tendrían razón ni necesidad de existir más que en función de la literatura misma, a la que se refieren, interpretan o valoran y sobre la que reflexionan o especulan». Era lógico, también, identificar esta ciudad de la crítica con el avisado, y casi decretado por Hillis-Miller, final de los tradicionales estudios literarios.

22 Tanto la introducción como la disposición de los artículos primeros, a modo de pórtico en Lecturas, obsesiones y otros ensayos (Steiner 1990: 11-223), denotan una declaración 
No es necesario estar de acuerdo con el «personalismo» romántico para saber que es un mero artificio intentar inmunizar los significados de una obra literaria de la vida y el medio del escritor. De ahí mi alegato en pro de la «crítica antigua», en pro de un entendimiento de la literatura como una «humanidad central», entendimiento que utiliza simultáneamente los modelos filosóficos y lingüísticos de tipo tradicional, sobre todo los que se encuentran en Coleridge y Roman Jakobson y en los puntos de vista marxista-existencialistas de Lukács y de Sartre (Steiner 1990: 13).

Y de ahí, la necesidad imperiosa de denunciar la falsedad de los postulados inmanentistas cuando tiranizan la apertura del texto: nada hay fuera del contexto, que solo se reconstruye con una hermenéutica que comparta frontera con la ética a través de los límites de la responsabilidad (Steiner 2011: 36-37) del crítico, un sirviente del texto, un mediador que únicamente puede sentirse abrumado asumiendo previamente su derrota ya que su encuentro personal, la huella que la Literatura deja en nosotros, se convierte en una deuda de amor.

El interés formalista por rehuir las respuestas subjetivas no ha podido evitar nunca que otra crítica se ofrezca como ese discurso mediador en el que insistía al comienzo. El grado de servidumbre necesario se ha querido confrontar con una crítica descriptiva ausente de conceptos morales, con el riesgo añadido de caer bajo la utopía de la experiencia literaria en tanto iluminación mística, encuentros en límites próximos a la revelación o la mirada gozosa dentro de lo inefable. En la tarea de resolver los enigmas del texto, el crítico no puede actuar como si no existiera a la vez una finalidad de consenso ${ }^{23}$ entre la utilidad y el desinterés, propios de una concepción específica de lo literario que conlleva su aceptación como una forma de conocimiento, como algo más que un arte. De alguna manera, la teoría de la literatura estructural se deshizo rápidamente, por imitación de otros saberes y ciencias, tanto del presupuesto ético como de su consecuente de valor, tan cercano a la estética como a la moral, deseosos de que la falta de evaluación propugnara un conocimiento más fiable y universal, más objetivizado. Para ello bastaría con construir un discurso ilocutivo con juicios derivados de principios universales (Booth 2005: 121 y ss.) o un acuerdo para la búsqueda común de la verdad en una especie de crítica convivida que entremezclara literatura y moral como en un diálogo filosófico (Todorov 2005: 179). Por otro lado, el humanismo crítico no puede justificarse a sí mismo ya en el siglo XXI con un ataque fronta ${ }^{24} \mathrm{o}$ una negación

de principios unitarios y sólidamente establecidos, a pesar de tratarse de un volumen que recogía artículos y highlights de libros desde 1958 a 1984.

${ }^{23}$ No quisiera hacer creer que ignoro que dicho consenso, en muchas ocasiones, o se ha roto o se ha actuado como si no existiera, aun existiendo.

${ }^{24}$ Por ejemplo, en el desmontaje descarnado pero muy certero, no exento de sanísimo afán polemista, en Aullón de Haro (2013). También se ha optado por culpar a alguien en concreto de todos los males generalizados; en este libro, en concreto, a «la trampa Jakobson», 
extrema de los planteamientos teóricos inmanentes ${ }^{25}$, por el simple hecho de que la literatura trate, como es lógico, de la existencia humana.

Ello, entre cuestiones tan interrelacionadas entre sí, que van desde la construcción de un discurso crítico a la concepción de la literatura misma, del papel comunicador del crítico frente a su labor enjuiciadora o descriptiva, de la validez de los significados a la fuerza del lenguaje para reflejar la realidad o presentar fantasmagorías, etc., vamos a limitarnos a analizar un modelo preciso de pensamiento ético-literario. Tal vez así podamos juzgar si aquí se cumple la pretensión de que el crítico acabe teniendo un sistema, no que empiece con él' ${ }^{26}$.

\section{El Pensamiento Ético-literario de George Steiner}

En los libros de George Steiner suele haber, aunque se trate de colecciones de conferencias, una rebuscada intencionalidad por atraer al lector con una expresión feliz, un pensamiento sentencioso y a la vez climático, propio del ornato vehemente, dispuesta al comienzo o al final del texto. A veces en ambos lugares. Suyas son: «No nos quedan más comienzos», «La verdad, creo, tiene futuro» o «Seguimos hablando todavía de la "salida" y de la "puesta" del sol» ${ }^{27}$. El efecto que transmite al lector este adorno no suele coincidir con un cierre emocional del discurso sino con la expectativa de necesitar otro texto, un nuevo libro, la continuación de un discurso inacabado. Quienes apreciamos las extremadas sensibilidad y cultura de Steiner $^{28}$, y la inmensa capacidad que posee para conjugar esos conocimientos, sabemos que nuestras ansias de continuar inmersos en la historia infinitamente, como en un buen novelón decimonónico, iban a ser en breve satisfechas con un nuevo estudio o monografía. Dejando aparte, por ejemplo, sagacísimos ensayos acerca del lenguaje y de la traducción, de la tragedia clásica y sus manifestaciones, o sobre Heidegger ${ }^{29}$,

por otro lado ya desactivada hacía tiempo. O en el caso de Compagnon (2015), sobre Roland Barthes.

${ }^{25}$ Podemos señalar en Culler (2007: 9, 11 y 22-28) las contradicciones de su vecindad con la teoría postformalista, encontrando algo distintivo en la literatura en resquicios pervivientes de la literariedad, en la demanda de claridad del modelo lingüístico como instrumento para el análisis literario, en su explicación del concepto de agency...

${ }^{26}$ En Black (1978: 177): «An orientation, together with taste and intelligence, is all that the critic needs. If his criticism is fruitful, he may end with a system, but he should not, in our present state of knowledge, begin with one.»

27 Steiner 2001b: 11; 2001a: 132; 1998a: 13.

${ }^{28}$ En donde la ausencia de lo español y lo hispánico — si se prescinde de Don Quijote y de Borges - denota un vacío siempre incómodo para un profesor de literatura comparada.

${ }^{29}$ No pretendo abarcar toda la obra publicada de George Steiner, sería demasiado pretencioso por mi parte y excedería en mucho el problema de una propuesta ética como base 
la serie que comprende desde Presencias reales hasta La poesía del pensamiento, entre 1989 y 2012, se revela íntimamente unida a través de un engarce que alimenta y ahoga indistintamente el propósito de cada uno de esos textos. Me refiero, como señalé arriba, a la presencia de Dios y a su necesidad última como elemento cohesionante de la estabilidad del mensaje poético y, sobre todo, de la intencionalidad ética del artista y de los receptores, incluido el crítico. Así como para el primer Platón el poeta era un hermeneuta, un intérprete de intérpretes, que como ser inspirado era poseído por los dioses, para Steiner la presencia de la Divinidad, o más concretamente de la palabra de Dios, deviene un supuesto necesario para poder responder al misterio de la creación poética. También a cada uno de los elementos que cohesionan el esquema comunicativo artístico, o sea, el autor, la obra de arte, el receptor y, muy obligadamente, el crítico. Y, por supuesto, el elemento envolvente y entrópico: una ética emanada de la necesaria existencia de $\operatorname{Dios}^{30}$. Esta conflictiva propuesta nace como un elemento voluntarioso de idealismo crítico, muy cercano al primigenio idealismo platónico, y más que nada al sentimiento armonioso que deriva del kósmos, del «orden bello», que sostiene la estructura armónica del universo a la manera en que los neoplatónicos, cualquiera que haya sido su escuela, interpretaron el Timeo, que para ellos formaba parte nuclear de la entraña de la enseñanza platónica. Bien, Belleza y Verdad, la kalokagathía griega y los tres soportes de la Gran Teoría estética hasta mediados del siglo XIX ${ }^{31}$, parecieron agotarse en un hegelianismo tan absorbente que hubo de ser desmantelado desde sus entrañas hacia el materialismo, el positivismo y la fenomenología. Desde ese momento de dispersión hasta hoy la desconfianza sobre la esencialidad y perennidad de la comunicación, en todos sus niveles, no ha hecho sino incrementarse.

Steiner medita sobre este problema radical para la crítica literaria circunscrito en la realidad postestructuralista que nos conduce casi hasta nuestros días. Como un Platón ${ }^{32}$ desengañado y anciano, preanuncia los desastres y los atri-

para una crítica personal. En la bibliografía final ofrezco, sin embargo, relación de una gran parte de sus libros traducidos al español, que no es completa, pero se citan los más relevantes, exceptuando Tolstói o Dostoievsky, de 1959, donde por cierto, ya aparece, por confesión propia (Steiner 2006: 140), «la dimensión teológica, la cuestión de la existencia de Dios». He señalado, además, la edición original de la que se traducen los textos, exceptuando aquellos casos en que se editan en el mismo año.

30 Para un exhaustivo estudio de una estética teológica, remito al deslumbrante trabajo en 7 volúmenes de Hans Urs von Balthasar, Gloria (1985-1989).

31 En lo que afecta a la Poética, véase González Alcázar (2005: 113 y ss.).

${ }^{32}$ Un lector asiduo de Steiner no apreciará abuso en esta comparación, toda vez que el pensamiento platónico y su autoridad como inicio estable de una cadena de seguridades filosóficas que no debería romperse impunemente - incluso el ensayo dedicado a Heidegger (Steiner 1999) lo manifiesta-, alumbra toda su obra. En este sentido hay en Steiner un patrón tipificado de recurrencias hacia Platón y su secuela platónica, constancia que provo- 
buye, en el fondo, a la falta de verdadero impulso ético. Pero su pudor y su propia consideración elevada hacia las manifestaciones artísticas le impide, en un primer momento de incertidumbre y cuando empieza a vislumbrar que su viejo mundo se le cae en pedazos alrededor, achacar esa falta de esencialismo a nadie más que a los intérpretes, ya se trate de teóricos o de críticos. Las conclusiones, más comunes de lo que aún nos parece ${ }^{33}$, ya escenificaban un panorama desolador dentro del mundo académico por la degradación e ideologización del juicio moral, propias de la corrección política:

Sin embargo, lo que con excesiva frecuencia ha venido a continuación ha sido una farsa de la argumentación y la investigación responsables. Se han ensalzado textos folclóricos, subalfabetismos y antialfabetismos artificiosos y publicitados a bombo y platillo. Se han institucionalizado planes de estudios a costa de disciplinas imprescindibles, creando no una liberación sino nuevos guetos para los afroamericanos o los chicanos. Se ha reescrito la historia hasta llegar a la parodia. Lo cierto es que, para bien o para mal (me he pasado toda mi vida profesional insistiendo en la cuestión de las correlaciones entre las humanidades y lo inhumano), nuestra herencia en Occidente es la de Jerusalén, Atenas y Roma (Steiner 2004: 137).

Ya en las charlas radiofónicas de 1974 que compondrían Nostalgia del Absoluto nos avisaba de la decadencia del papel de los sistemas religiosos formales en las sociedades occidentales y su rápida transformación en mitologías sustitutorias ávidas de rellenar el hueco, «el inmenso vacío», «central», producido por la muerte de Dios (Steiner 2001a: 15). Esas mitologías se caracterizan por ofrecerse, como las verdaderas religiones, dentro de un sistema totalizador, con formas reconocibles y un lenguaje propio ${ }^{34}$. Las herejías y la

ca una culminación en su reciente ensayo (Steiner 2013: 56-70), anonadado ante la «riqueza material» de sugestiones que hace tiempo encuentra en la obra del filósofo, al que vuelve una y otra vez. Si bien, no trato de incluirlo en la nómina de escoliastas o exégetas; más bien, un lector cercano, un profesor que formaliza su pensamiento y un ensayista que se inspira en lo que conoce y admira. Y que escribe del ateniense: «Ningún filósofo ha tenido una conciencia tan vulnerable del poeta que había en él como Platón.» (Steiner 2001b: 63). La relación es señalada con insistencia por la crítica más atenta, véanse las breves pero aclaratorias palabras de Garrido Gallardo (2004: 357) al respecto de la «higiene intelectual y el afán provocador» de Steiner y su atención sobre una nueva República platónica donde se expulse a «los que dilapidan su esfuerzo en críticas inflacionarias o de segundo grado».

${ }^{33}$ Estoy pensando en la repercusión que ha tenido el libro de Jordi Llovet, Adiós a la Universidad. El eclipse de las Humanidades (Barcelona: Galaxia Gutenberg-Círculo de Lectores), de 2001.

${ }^{34}$ Un motivo de engarce con la teoría crítica de la escuela de Chicago (en cuyos albores se educó el joven Steiner, alumno de Richard McKeon, aunque también de los new critics Allen Tate y R. P. Blackmur), a través de la mitología de la presencia en la explicación formalista del poema como un platonismo retrógrado, que sanciona Murray Krieger (1992: 252-253) en fechas cercanas de 1976; este último, no se olvide, además de pertene- 
simbología negativa eran sus pares necesarios. Observaba en aquel momento tres modelos perturbadores pero capaces de actuar en el papel sustitutorio: el marxismo, el psicoanálisis y la antropología ${ }^{35}$. Debemos recordar que dentro del pensamiento literario los tres saberes conformaron, aunque de esto apenas hable Steiner, una raíz de confluencias sin las que, junto a la fenomenología y la lingüística, es imposible entender la teoría y la crítica literarias del siglo XX. Por otro lado, el sistema de las viejas religiones de Estado, propiciadoras de respuesta global y de límites precisos y fijos a través del tiempo, pierde su papel en Occidente ante tres mitologías, curiosamente dominadas por pensadores que responden a una tipología concreta de la naturaleza judía: el mesianismo profético de Marx, el valor de la palabra en Freud y la alianza del hombre con la creación en Lévi-Strauss. Como respuesta, el ser humano, insatisfecho, busca la solución afuera. Sucede ahora — década de los setenta-, que la sociedad estadounidense, y después la europea para su desdicha, anda inmersa en las corrientes de la contracultura, auténtico disolvente del eternalismo burgués. En consecuencia, enjuicia con estupor ${ }^{36}$ que nuestra sociedad echa en falta un modelo final, una bóveda sobre la que poder cerrar la cúpula de las últimas verdades. De tal modo que los jóvenes, y los no tanto, de Occidente buscan en los extraterrestres, en las filosofías orientales - abundantes de un dualismo burdo entre mente y cuerpo-, en ocultismos varios, aquello que tapará las grietas por las cuales el frío no penetre en los huesos de un sistema de vida. Sabemos que esta airada reacción contra cierto sincretismo cultural de los años setenta y ochenta era compartida, con matices, por numerosos intelectuales insatisfechos ante los primeros pasos de lo que después se llamó globalización: recuérdense los chispeantes artículos de Umberto Eco en La estrategia de la ilusión (1983). Lo que parece una experiencia personal, pesimista, un volver la vista a aquel pasado que fue mejor, se transforma en un reconocimiento de la necesidad de tener al lado una verdad, aunque sea subjetiva, similar a la promesa evangélica de que esta $-\mathrm{u}$ otra — verdad nos hará libres. No oculta

ciente a dicha escuela aristotélica, fue el primer catedrático de Literary Criticism en los Estados Unidos desde 1963, una vez liberado este estudio de los departamentos de lenguas.

35 Sin afán de ser exhaustivo, dentro del marxismo y hacia las sociocríticas diversas, se impulsa la relación de la obra literaria con su referente externo, y de ahí hacia los estudios culturales y las diversas teorías sistémicas; el psicoanálisis, respecto de las modalidades de la creación, neuróticas o no, abunda hacia una nueva visión del creador y de su capacidad de producir imágenes, a través de la mitocrítica o de la poética del imaginario; la antropología de Lévi-Strauss, en la base del estructuralismo, transforma la concepción formal de la literatura y sus constituyentes, y revaloriza el elemento ficcional.

${ }^{36}$ Y lo hace rodeado por guturales aullidos, estrambóticos riffs guitarreros y demás parafernalia rockera que desprecia profundamente. Escribe sobre ello (Steiner 2006: 126): «Está hecho para ensordecer; es totalmente sádico; está hecho para humillar. Yo lo asocio con el fin de nuestro sentimiento de la armonía de la vida.» Quizás no sea pertinente, pero me permito disentir. 
Steiner que el camino será arduo, que «la verdad es más compleja que las necesidades del hombre», pero nuestra labor más importante consiste en plantearse preguntas y tratar de lograr respuestas. Concluye resumiendo, curiosamente, como hizo de manera similar Ortega ${ }^{37}$ treinta años antes:

La búsqueda desinteresada de la verdad en el sentido en que Descartes o sir Karl Popper la comprenden — como sujeta a falsación, a la prueba experimental, al imperativo de la lógica- no es universal. [...] En otras palabras, la persecución de la verdad es desde el principio una verdadera persecución. Tiene elementos de caza y de conquista. Hay un momento característico en uno de los diálogos de Platón cuando, al final de una muy difícil demostración lógica, los discípulos y la multitud, en pie, lanzan un auténtico grito, «iAuuh!», cuando ha acorralado a su presa (Steiner 2001a: 114-115).

Así pues, una nostalgia del Absoluto que nos sumerge directamente en las cercanías del kósmos griego, al que vamos a pedir no solo un orden bello sino, como pensaba Platón, educativo y formativo. Y como añadiría Plotino a su maestro, virtuoso.

De ahí la necesidad inferida de que el discurso secundario sobre el arte no siembre dudas sobre su naturaleza por más que esta sea lábil o compleja. El problema sucede en el momento anterior, cuando se duda del lenguaje mismo como portador de significado. Me refiero, por supuesto, al choque con la deconstrucción, que Steiner explica como final de un proceso enconado desde la actitud del Crátilo platónico llevada a su mayor extremo al considerar que de ninguna relación entre cosas y palabras, de la imposibilidad de reproducir «ninguna figura de las cosas» (Steiner 1998a: 132 y ss.), hayamos acabado por dar la espalda al lenguaje natural. En su concepto de post-palabra (after-word), la escuela deconstructivista ha heredado la jerga sin sentido del psicoanálisis de todo nuestro mundo actual a través del juicio de Fritz Mauthner en 1899: «El discurso que teje instituciones sociales, el de los códigos legales, el debate político, la argumentación filosófica y la elaboración literaria, el leviatán retórico de los medios de comunicación: todos estos discursos son clichés sin vida, jerga sin sentido, falsedades intencionadas o inconscientes» (Steiner 1998a: 138-139).

No incidiré en el recurso inevitable contra los desánimos deconstructivistas, únicamente recordaré que para Steiner las palabras de Derrida sobre la concepción teológica de la era del signo demuestran con creces su individual punto de vista acerca de la necesidad de una autoridad, de una «presencia real» ${ }^{38}$ (Steiner 1998a: 212-227), que ponga orden en el Logos y que justifique la finalidad ética del arte. El problema, enquistado en las últimas décadas, es que

37 Véase el comentario a idénticas expresión y símil platónico en nota 1 al final del Prólogo a Veinte años de caza mayor del conde de Yebes (Ortega y Gasset 2006: 332-333).

38 Según tituló, con feliz hallazgo, un artículo de 1985 (Steiner 1997: 96-71). 
la sospecha excluye cualquier presencia y propone en el fondo un modelo de creatividad profano que le resulta tan paródico como la deconstrucción respecto de la estética de la recepción: tan absurdo como proponer un juego eterno sin juez supremo, del que no se puede salir y al que inútilmente lanza una pregunta retórica. Si no hay porqués en un texto, entonces por qué leer, por qué escribir:

La ruptura con el postulado de lo sagrado es la ruptura con cualquier significado estable y potencialmente comprobable del significado. Cuando se ha disuelto el principio propuesto por la teología y la metafísica de una individualidad continua, de un yo coherente desde el punto de vista cognoscitivo y éticamente responsable [...], no puede existir ni la «universalidad subjetiva» de Kant ni esa creencia en la búsqueda compartida de la verdad que, desde Platón hasta nuestros días, desde el Fedro hasta hoy, ha garantizado los ideales de la religión, el humanismo y la comunicación. Esta misma imposibilidad es la que define la modernidad (Steiner 1998a: 164).

Con toda seguridad, el excelente lector de Platón que es Steiner conoce profundamente los entresijos del Fedro y su posición liminar respecto de la crítica literaria al asumir las lecturas alegóricas de los mitos, la distinción - ya alejandrina, no lo olvidemos - entre contenido y forma y el juicio positivo de la manía poética que posee al poeta conduciéndole hacia la verdad y su conocimiento. Es decir, antes de que el Idealismo estético recree su propio platonismo, entre la desmesura de la forma como corporeización de la idea de belleza y el desinterés kantiano y hegeliano. Steiner afirma claramente que no debe situarse al arte por encima del bien y del mal, al contrario, lo que nos provoca la emoción artística «trae consigo obligatoriamente el bien y el mal» (Steiner 1998a: 177). Por ello la esteticidad se presenta íntima a nosotros, por ello las censuras a la poesía y la quema de libros. Si el arte estuviera por encima de los valores del hombre sería un artefacto lúdico exento de interés. Y no puede ser así, toda vez que partimos del hecho de que frente a las modernas escuelas de la sospecha y las diversas teorías del significado, es necesario restaurar la confianza en la relación directa entre Logos y Divinidad, o entre Logos y Cosmos, la natural alianza entre la palabra y el mundo.

Otro tipo de complejidad se rastrea en el concepto de cortesía (Steiner 1998a: 182 y ss.). Aquí nos damos de lleno con la centralidad del eticismo de su pensamiento, como se deduce de la polémica sostenida con Hans Belting (Jauss 2012) en torno a esta nostalgia de la divinidad y al envolvimiento moral de la tendencia a la otredad como consecuencia inevitable. Así pues, la ética religiosa que preside el fondo del mensaje poético está también presente en la relación responsable entre el autor, los receptores de su obra y el crítico en tanto categorías de exigencia ética. El ser humano, por su parte, es libre de no recibir, de no querer someterse a la experiencia estética. Pese a todo persisten unas constantes en la presencia de los otros que son las que justifican el pre- 
guntarnos la causa de la existencia del arte y su finalidad. Esa cortesía articula las relaciones del esquema comunicativo artístico y establece prioridades. Nos enseña cómo leer, cómo expresar confianza en lo que leemos y cómo abordar el comentario de las obras artísticas. Acaso tal principio y su condicionante otredad rehagan el papel inequívoco del demiurgo en la cosmología platónica. Salvando todas las distancias, es una presencia que motiva, si no la simetría de lo Bello y su estructura armónica, sí la bondad de un orden invisible y la necesidad de un dios, menor si se quiere, pero tan eterno como cualquier otro, con cuya realidad condicionada se justifica la presencia de lo religioso en el acto de la creación y de la contemplación. No en vano la respuesta más proclive ante la Belleza es el silencio:

En el nivel de la poética y la retórica, el motivo de la insuficiencia semántica es bastante antiguo. Por ingeniosas, por inspiradas que sean, las palabras del poeta o del filósofo se quedarán cortas frente a las numénicas intensidades de ciertos fenómenos y estados del ser sentido. El aura de ciertos escenarios de la naturaleza, de ciertas intimidades de deseo o dolor se resiste a ser transferida comunicativamente al habla. La única respuesta correcta al misterio de la belleza de Helena y a la aparición de Eros a su paso no es habla sino silencio (Steiner 1998a: 116).

Nunca mejor que en aquellos pasajes en que Steiner da rienda suelta a sus aficiones musicales y observa, con razón, la universalidad imposible de la literatura, siempre ligada a la posesión del lenguaje y ahora a la sospecha, frente a la universalidad natural de la música, tan solo dependiente de la ejecución ${ }^{39}$. El formalismo en la música es inherente a su naturaleza, significa siempre. La tendencia a la pureza de la experiencia estética en la música y en las matemáticas, son constantes persistentes en la obra de Steiner ${ }^{40}$. Así como las matemá-

39 Cabe aquí recordar que Platón opera de la misma manera, aunque en su República ponga reparos ante el poder de la magia compositiva para distraer de la verdad y su componente imitativo, y por tanto inmoral, presente en la estructuración de la poesía entre Logos, armonía y ritmo. La teleología innata en el pensamiento platónico se trasplantó, es conocido, a Plotino junto con el prejuicio antimimético originando un nivel secundario en la Belleza artística.

${ }^{40}$ Es muy probable la influencia de Frye (1977: 30-33) en esta consideración general, de tipo antropológico, hacia una unión de artes y saberes, como elementos nucleares de la psique humana, aunando literatura, matemáticas (cabría recordar en esta relación, junto a la teología, a Alfonso Reyes) o física, y, desde luego, las otras artes, significativamente la música. De esta íntima unión, tal vez, junto a la pintura, la más duradera experiencia de creatividad conjunta, la bibliografía sería inagotable y se ha convertido en un lugar argumentativo común (i. e. Rancière 2009: 171-178) para intentar equilibrar la pertenencia de la literatura al correlato del sonido o de la imagen, en ocasiones, en tanto opuestos. Sobre el ser humano como creador de formas hacia una proyección existencial, véase Krieger (1992: 138). 
ticas, la literatura también opera por combinación y como ellas, en el caso extremo de la poesía, solo se busca a sí misma, se afana en ir al reino de lo Absoluto (Steiner 2001b: 190 y ss.).

En La poesía del pensamiento (Steiner 2013), acerca de la búsqueda de un orden común entre literatura y filosofía, se traza un camino de similitudes entre ambas maneras de encontrar una respuesta tanto para lo sustancial, lo perenne y lo duradero, propia de la metafísica occidental cuando esta ha pretendido lo inefable, como para el fondo inalterable de la creación poética. No es difícil leer entre líneas que esta intensa colaboración a lo largo del tiempo, empezada por los presocráticos y Platón sobre Homero y Hesíodo, y culminada, cómo no, con la tortuosa relación entre Heidegger y Paul Celan, se basa en la existencia de una metáfora primigenia que filosofía y literatura han tratado de resolver basándose en el lenguaje como instrumento común: «Lo inefable, en el sentido directo de esa palabra, circunscribe a los dos. La poesía aspira a reinventar el lenguaje, a hacerlo nuevo. La filosofía se esfuerza por hacer el lenguaje rigurosamente trasparente, por purgarlo de ambigüedad y confusión» (Steiner 2013: 227).

Igualmente hay una muestra de esta gradación de cercanía con lo divino en la prioridad del tiempo creativo. A veces olvidamos, según Steiner, que el poema podría no existir, que es anterior a toda recepción o comentario, y que por su naturaleza temporal primaria ya ha establecido un modelo tendente hacia la receptividad, por consecuencia, hacia toda comunicación en la que nos encontraremos frente un acto de confianza por la presencia de un significado ${ }^{41}$. No se trata aquí de negar toda teoría significativa ya que el comentario crítico o el comentario lector no tienen ni deben de tener fin. La existencia de variedad de lecturas y de interpretaciones confirma la prueba precisa del valor de lo artístico, de su necesidad para generaciones y generaciones de seres que han poblado el mundo. Ninguna propuesta estética es verificable ni puede suplirse por el contexto (Steiner 1998a: 84 y ss.). La necesaria pertenencia del arte a su época y momento supera la condición secundaria de moda.

Cabría preguntarse, llegados a este punto, por la raíz de esta crítica literaria y su consecuente opción ética. Sobre esos parámetros de relación y conviven-

${ }^{41}$ No se olvide que Steiner ha ejercido una intensa labor académica en Ginebra. A pesar de su locuacidad en otros aspectos, sorprenden muchos silencios en torno a ciertas similitudes con ideas cercanas a la crítica de la conciencia. Si hubiera nacido una generación antes, no dudaría de que por esta, y otras afirmaciones, Poulet le hubiese incluido junto a Raymond y Béguin en La Conscience critique (1971). Por otro lado, aunque ya se ha aclarado que no había en este artículo una voluntad de exhaustividad ni en caso de Steiner ni en el decurso teórico-crítico, no obstante, sobre la relación no tan homogénea entre el pensamiento anglosajón y el europeo sigue siendo utilísimo pese a los años transcurridos, más que la enciclopédica Historia de la crítica moderna de Wellek, el libro de Frank Lentricchia (1990) al que vuelvo a remitir. 
cia, la contribución de Steiner puede distribuirse sobre tres movimientos de impulso ético interconectados: el que lleva del autor a la obra, el que transmite la obra al lector y el que justifica la presencia y la tendencia al Absoluto.

En primer lugar, la fiabilidad del autor al responsabilizarse éticamente de su obra sugiere un símil con el presupuesto de que la existencia de Dios está basada en la creación: solo Dios puede crear y solo Dios crea (Steiner 2001b: 31 y ss.). Y Dios no hace otra cosa que crear mediante la palabra, de ahí la especial delectación de Steiner en repetir la desconcertante tautología bíblica de la zarza ardiendo: «ego sum qui sum», según la Vulgata. Ni por un instante se pone en duda la seriedad de esta compleja afirmación por más que un Dios riente y hasta travieso reflejaría más abiertamente su humanidad en esas palabras. Por tanto, la creación obedece a criterios poéticos, filosóficos y teológicos. Y tiene su correlato: es un supuesto poético-estético, verdadero ${ }^{42}$ y ético. No obstante, la esencialidad clásica y clasicista del arte en torno a la mímesis perturba esta natural equivalencia, como él mismo hubo de reconocer en Gramáticas de la creación. Es preciso conjugar el eternalismo griego con el creacionismo judeocristiano; de esa manera explicará el proceso creativo, dentro del neoplatonismo, el diálogo Timeo (Steiner 2001b: 63-66), como una gramática entrelazada por dos esencialismos éticos: el previo a la obra artística, cuya moralidad protege frente al desbordamiento de la manía inspiradora y la finalidad de la misma, con cuyas belleza y verdad se cautiva a la correspondiente belleza del cosmos limitándole, dándole sentido y razón, y dejando fuera el caos: «En la gramática de la creación propuesta en el Timeo, la palabra kalós significa lo que es virtuoso de forma, lo que es armónico cuando se relaciona con otras cosas y lo éticamente admirable. En ninguna otra parte lo teológico, lo metafísico y lo estético se han unido de manera más íntima» (Steiner 2001b: 66).

A diferencia del frío y artesano demiurgo platónico, el Dios hebreo crea ex nihilo y además a su imagen. La continuación inveterada de crear sobre invenire o роіеo son dos caras del misma moneda para Steiner. Supone únicamente un cambio de sistema teológico. El demiurgo platónico fue libre para no crear, pero, ¿Dios lo es? De la misma manera que una vez creado el cosmos este es inmortal, así la creación divina es un acto de libertad que no culminará nunca. He ahí la garantía de la perdurabilidad estética. Para el ser humano esto es difícilmente comprensible, ya que toda nuestra creación es efímera y se destruirá algún día (Steiner 2001b: 124 y ss.). Deberíamos de ser capaces, continuando con este razonamiento, de reconocer dentro de la naturaleza de la obra poética los motivos que reflejan esta pretensión de totalidad. Recordemos que para Platón, con excepción de algunos mitos y alabanzas a los dioses, por

${ }^{42}$ Sorprende, sin embargo, la ausencia de interés en preguntarse qué tipo de verdad hay en la poesía, es decir, qué relación se puede establecer entre poesía y realidad, aunque esta pertenezca al espacio imaginativo y aunque esto suponga comenzar otra vez a girar sobre el eje platónico. Véase en González Alcázar (2010: 125-138). 
tanto, composiciones que contenían una temática cercana a los fundamentos de su religión, todo el resto de la poesía llega a calificarse de prescindible. Steiner no prescribe tal desmoche ni tan desmesuradamente, aunque se debería objetar contra este maximalismo personal por la tendencia a fijar sus contradicciones sobre obras maestras incuestionables, en las cuales la histórica valoración ético-moral prima sobre el formalismo, actitud tan reveladoramente antimoderna ${ }^{43}$ como la del Platón de Las Leyes a que antes aludía. Notemos, al respecto, la especial delectación con que repite el recurso tan caro para él de la inmensidad incontrolable de estímulos artísticos y de los nuevos medios tecnológicos de difusión, convirtiendo el mundo cultural en una asombrosa indigestión. ¿Cómo ordenar ese caos?, ¿qué papel puede ocupar la memoria? (Steiner 2001b: 296 y ss.).

En segundo lugar, sobre el desplazamiento ético que conduce desde la obra acabada hacia la recepción, Steiner considera que se basa en la referencialidad de lo ficcional. Y es el momento de máxima tensión y de mayor alejamiento frente a esta visión platónica del arte como paralelismo, reivindicado por él, de crítica ética ${ }^{44}$. El problema consiste, según cree, en que mímesis y creación son en realidad el mismo proceso creativo, pero sostenidas ambas por dos conceptos teológicos distintos. En el judeocristiano, la existencia de un Dios que crea desde la nada y habita entre nosotros incita a trasformar mistéricamente lo creativo en un modo de hacerse presente, en una encarnación (Steiner 2001b: 74 y ss.). La conciencia de imitatio, alegoría del artista tratando de hacer lo que hace Dios como modelo de vida, remite a una verdad diferente, contraria incluso, a la condena platónica de lo ficticio. Así pues, en esas ficciones no debemos pretender enfrentar a la literatura con la verdad, al modo de Platón, sino entender que se trata de una figura veritatis, una recreación que solamen-

${ }^{43}$ No tanto por oposición a principios nacidos en la modernidad de la Revolución Francesa, como aquellos evocados por Compagnon (2007) en resistencia a un ingenuo concepto de progreso, cuanto por una necesidad de justificación educativa de la experiencia artística, presente desde siempre en el pensamiento literario, y reforzada en Steiner por el didactismo victoriano, herencia, para la crítica literaria, de Arnold: «Dicho más enfáticamente, las motivaciones de la investigación literaria del siglo XIX fueron moralistas o históricas. La tradición moral va desde el doctor Johnson hasta Matthew Arnold y, más recientemente, hacia Leavis, y la tradición histórica es la de Sainte-Beuve y Taine, cuyo heredero contemporáneo sería Edmund Wilson» (Steiner 2002: 144).

${ }_{44}$ Siendo los dos casi ficciones, hay una radical diferencia entre la lectura del crítico y la del lector, ya que aquel a veces compite con el texto y declara aquello que el lector debe vivir en silencio. El primero tiene ante sí una labor del ego, el lector solo es su sirviente. Las implicaciones de esta dualidad son revisadas en profundidad en 1979, en «Crítico / Lector» (Steiner 1990: 92-131). Sobre los cambios de los hábitos lectores en nuestra era electrónica y las dificultades de comprensión, atención o incluso concentración, conducentes a la transformación de la cultura en un simple entretenimiento, remito a un artículo de 1978, «El lector infrecuente» (Steiner 1997: 19-44). 
te pasa a ser considerada fantasía en la modernidad. Él mismo propone conducir este proceso dúplice entre la construcción demiúrgica y la creatio ex nihilo hacia una combinación sobre la idea de invención. La invención permite apuntar a las fuentes en una suerte de teoría de la reminiscencia, de modo que unimos el proceso artístico a lo trascendente: «Estas soluciones, que fundamentalmente son una, abolirían la dualidad, la fuente del gnosticismo que opera en la filosofía y en la estética tras Platón. El espíritu se hace inmanente a la forma poética pero el impulso hacia la universalidad comunicativa y hacia la "intemporalidad" en el lenguaje, "trascendentaliza" esta inmanencia» (Steiner 2001b: 131).

En la poesía percibimos esa creatividad del lenguaje, que en principio es inaccesible, a lo que Steiner llama «figuras primigenias». Señala aparte algunas especificidades de la realidad en la literatura que somos capaces de asumir como lectores, pues la literatura nos predispone frente al idealismo, toda vez que este separa sujeto y objeto, hecho imposible en la creación poética (Steiner 2001b: 168 y ss.). El lector, en estos casos, ha interiorizado sentimentalmente a los personajes, les ha conferido una realidad poética distinta al referente, pero igualmente tangible. Del rechazo platónico surge inevitablemente la contrapartida en Aristóteles, otro dualismo inexacto pero pertinazmente productivo, sobre quien Steiner hace descansar la responsabilidad de ser el primero que pudo ordenar el modelo ficticio al renunciar a volcar sobre el arte el principio de verdad y dejar reducida la mímesis a ficciones aparentemente heterocósmicas. Las ficciones son espejos y tal vez el Sócrates de los Diálogos sea solamente la ficción suprema de Platón. Hemos de asumir que lo ficticio, en tanto receptores, nos importa porque el arte, con sus condiciones de participación ética, nos obliga a conferirle vida, existencia real, un aliento vital que también nos convierte en parte del reflejo primario del Absoluto ${ }^{45}$. Como tal, su presencia es síntoma de un significado, por lo tanto, un acto de confianza y, como concluí arriba, ético.

El tercer y último movimiento, la tendencia al Absoluto, escrito y pronunciado con mayúsculas, nos obliga a regresar a Platón, en donde Steiner entiende que el verdadero poeta está poseído por el infinito. Tiende, según esto, a un concepto totalizador de eternidad de su acto creativo en una visión progresivamente idealizada de la jerarquía ética de la sociedad. Y no supone la tendencia al Bien moral. Es Dios, una necesidad o un supuesto, dos caras ambivalentes, alfa y omega del principio inicial y final del proceso creativo ${ }^{46}$. Cabría ahora

\footnotetext{
${ }^{45}$ Significativamente, el antiformalismo de Steiner, en tanto recusación de las disoluciones y negatividades postformalistas, se hace eco del alejamiento y estatismo a que induce el concepto técnico de forma, que toma en él la urgente necesidad crítica de llenar un vacío como en Blanchot sucede a través de la opuesta reacción de ausencia.

${ }^{46} \mathrm{La}$ identificación del oficio del poeta con el oficio divino, sobre todo en el acto creador, y la necesaria atención del crítico a ese rastro de divinidad que queda presente en
} 
concederse un momento para perfilar el retrato del profesor de literatura comparada, de origen judío, no practicante de ninguna religión ritualizada por confesión propia, postulando su propia sociedad ideal de artistas sin presencia de amargos críticos que, yendo a la zaga de las elevadas conclusiones de sus análisis, empezasen a ejercer su labor disolvente sobre la naturaleza, la finalidad o la valoración de la literatura y el objeto artístico, cuanto más sobre la inutilidad por impotencia de toda crítica literaria que nos arrastra hasta hoy. Y sí hay algo de impotencia ante las sucesiones contradictorias de escuelas y de conceptos teóricos a que yo aludía al comienzo cuando, llegando a destapar toda su amargura, nos conmina: «No se hará burla impunemente de la hipótesis de Dios» (Steiner 2001b: 341). Después se pregunta, algo tendenciosamente: «¿Puede, podrá el ateísmo suscitar una filosofía, una literatura, una música o un arte de envergadura?» (Steiner 2001b: 342). Reincidirá en otro lugar con mayor vehemencia: «¿Puede haber una comprensión de eso que engendra "textos" y que haga la recepción posible y que no esté garantizada por un postulado de trascendencia, por la "aspiración a la realidad invisible" de Platón?» (Steiner 1998a: 270).

Nuestra civilización, argumenta Steiner, perteneciente al orden textual ${ }^{47}$, ha establecido un problema ético desde entonces entre los textos sagrados y los poéticos, entre preceptiva y ficción. Cuando lo ficticio pasa a ser creación y luego invención ha llegado el momento de hacer una apuesta por la trascendencia (Steiner 1998a: 259 y ss.), y ejemplifica con la predisposición a la búsqueda constante de absolutos, de misterios, de otras filosofías, en las improntas estéticas de la contemporaneidad como el neoplatonismo de Kandinsky o el esoterismo teosófico del movimiento Dadá, o al modo en que lo hicieron los gnósticos ${ }^{48}$. Pero no es la única apuesta, también la crítica asume parte de

el poema, encaja perfectamente con su admiración («uno de los documentos más desconcertantes y fascinantes en la historia de la sensibilidad literaria y lingüística occidental») por las cuatro conferencias que Heidegger dedicó a Hölderlin junto a la trascendencia de sus otras lecturas de poesía que Steiner (1999: 238-245) celebra por encima de la «aburrida miscelánea de la crítica literaria y del comentario académico».

${ }^{47}$ En lo que se diferencia gravemente con la Grecia clásica, a despecho de las constantes alusiones a Platón. Véanse, por ejemplo, de Havelock, Eric A. (1994). Prefacio a Platón. Madrid: Antonio Machado libros y La Musa aprende a escribir. Reflexiones sobre oralidad y escritura desde la Antigüedad hasta el presente. Barcelona: Paidós, de 1996. Y muy cercano Ong, Walter (1987). Oralidad y escritura: tecnologías de la palabra. México: F. C. E.

${ }^{48}$ Algo similar viene practicando el último Harold Bloom (2005 y 2011), hambriento de sabiduría en los textos, o quizás en la misma oposición juvenil al New Criticism imperante en ambas formaciones académicas y primeras docencias. Steiner ha aludido a ello a menudo a lo largo de su obra, en puntuales ocasiones llena de apuntes biográficos. Quizás el lugar donde su formación se convierte en tema de ensayo y reflexión con más claridad haya sido en el capítulo 9 de Errata (Steiner 2011: 153-175). 
la idea de trascendencia por la búsqueda de la significación en un acto de lectura como incitación a la Verdad y, consiguientemente, al Bien:

La atribución de belleza a la verdad y al significado es un gesto retórico o una muestra de teología. Una teología, explícita o disimulada, enmascarada o confesa, sustantiva o imaginada, que garantiza la presuposición de creatividad, de significación en nuestros encuentros con el texto, la música o el arte. El significado del significado es un postulado trascendente. Leer el poema responsablemente (respondientemente), ser responsable ante la forma, es apostar por un reaseguro del sentido (Steiner 2001b: 261-262).

Sería descabellado, según parece, ir contra el misterio de nuestra condición, perteneciente a todas las grandes religiones por igual, por más que Steiner actúe a veces como un auténtico reborn respecto del Dios cristiano con sus alambicadas expresiones sobre la encarnación, el amor, la charitas o el Mysterium tremendum. Lo importante, lo más rabiosamente actual, incluso ahora, de George Steiner es ir a contra corriente, hacer asomar entre sus reflexiones algo que se tiende a ver hoy como inaceptable: la idea de que Dios, callado desde que habló con Job por última vez según el Viejo Testamento, nos habla a través del Arte y nos enfrenta a los fantasmas del formalismo lingüístico, negando - con cortesía algo forzada - a Wittgenstein al afirmar que los límites de nuestro lenguaje no son los de nuestro mundo (Steiner 1998a: 274). Pero la gravedad de su rebeldía le obceca inexorablemente hasta no ser capaz de admitir una relación profana con los textos, ni pretender encontrar algún tipo de universalismo estético. El olvido de la pregunta de Dios causa un debilitamiento, una banalización de la cultura y un cambio radical en la comprensión textual:

\begin{abstract}
Bien pudiera ser que el olvido de la pregunta de Dios sea el núcleo de culturas hoy nacientes. [...] Si estas mutaciones de la consciencia y la expresión entran en vigor, las formas de la creación estética tal como las conocemos ya no serán productivas. Quedarán relegadas a historicidad. Similarmente, los modos de respuesta y de encuentro hermenéutico, tal como los he esbozado, se convertirán en arqueologías. La filología ya no conocerá un Logos como objeto de amor (Steiner 1998a: 279).
\end{abstract}

Escribíamos arriba que la posición particularmente exitosa de Steiner, capaz de llegar a muchos lectores de muy diferente ámbito, ha debido provocar una idea muy parcial del rigor filológico, así como de las intenciones y metodología de la teoría y la crítica literarias en un público muy amplio y no mayoritariamente académico. Con todo, la impostura de unos ha dado sombra a la de otros. Steiner no parece en este asunto tan diferente al reclamar una general aprobación en el hecho de enfrentarse a los excesos de los metalenguajes con un espiritualismo casi contrarreformista con tal de superar a toda costa los 
desafíos de la deconstrucción, los estudios culturales o la nueva filosofía del lenguaje ${ }^{49}$.

El recurso, a veces escamoteado, de disfrazarse como un platónico estrafalario, dentro de la gravedad de la doctrina que propone, resulta por el contrario sugestivo y conecta con un ludismo y atrevimiento que a veces son necesarios y útiles ${ }^{50}$. Más aún cuando la perplejidad se torna ironía, cuanto menos al leer su firme negativa a aclarar si cree o no en esa Divinidad que, según hemos venido argumentando, sustenta teológicamente toda su teoría sobre el significado (Steiner 2008: 236-237). En ese mismo párrafo, líneas más arriba, declara su inmenso terror al vacío y ese vacío en ningún espacio lo siente tan significativamente como en la ausencia de Dios dando sentido al mundo, que ha perdido su referente y su aspiración moral. Cuestiones de fe aparte, el juego que propone desemboca en una ocurrencia muy antigua: creamos en los dioses aunque estos no existan. Ya que la verdad está ligada siempre a lo divino y nos permite ascender por ella hacia el Absoluto, al final del camino estético habremos llegado al Bien Supremo. Para encontrarnos en ese Bien, la experiencia literaria en particular habrá subido todos los escalones desde la misma identificación de mímesis con realidad a la superación inventiva, pasando por la sustentación moral de la finalidad que pretende. Steiner reviste de inmanencia trascendental a toda la experiencia artística y hace descansar sobre ella lo que para él son aspectos ancilares o secundarios de la hermenéutica textual: «Si mi intuición general tiene sustancia, la indiferencia a lo teológico y lo metafísico, a la cuestión de si los confines de lo pragmático y lo refutable de forma lógica y experimental son o no de la existencialidad humana, significará una ruptura radical con la creación y recepción estéticas» (Steiner 1998a: 279-280).

Ante la presencia de la Belleza se restaura de alguna manera el orden moral del mundo, la necesidad de armonía entre las partes, a menudo maltrechas por la locura y los crímenes que permanecen sin justicia. No obstante, esta última pretensión de ejercer un orden ético a través del arte parece imposible. Según nos dice Steiner, vivimos siempre en la promesa de un domingo liberador en el que estas prevenciones no sean necesarias. Llegados a ese momento

49 Conclusión que resulta aparentemente contradictoria con el autor de numerosos trabajos sobre los estudios lingüísticos y su relación con la literatura. Véanse, solo por citar y sin ir más lejos, los indisimulados escarceos con la lingüística cognitiva en «El lenguaje animal», los vivos reparos a la lingüística chomskiana en «El lenguaje humano (con algunos comentarios de Noam Chomsky)», ambos de 1969, o el señalado título «Lingüística y poética», de 1970, consecutivamente publicados en Extraterritorial (Steiner 2002: 113-162).

50 No me importa afirmar que es tan infrecuente destacar esta inclinación en Steiner cuanto hacerlo con el papel que suele jugar el humor y la creatividad en las argumentaciones del recientemente fallecido Umberto Eco. La comparación usual adquiere tintes sombríos: «El tono steineriano es litúrgico, rapsódico, y su respeto por la vida de la mente es casi religioso. Es, sin dudas, un rabino renuente, uno de esos refugiados heridos que proviene de las ruinas de la cultura clásica europea» (Eagleton 2012: 226). 
el arte en general y la literatura en particular carecerán de toda lógica y necesidad. Como, si vivimos para ver ese domingo, peligrarán nuestros oficios y por ende, nuestro modo de vida, confiemos que, en esto al menos, Steiner tenga razón y el «nuestro [sea todavía] el largo día del sábado» (Steiner 1998a: 280).

\section{BIBLIOGRAFÍA CITADA}

Asensi Pérez, Manuel (2011). Crítica y sabotaje. Barcelona: Anthropos.

Aullón de Haro, Pedro (2013). Escatología de la crítica. Madrid: Dykinson.

Baltasar, Hans Ur von (1985-1989). Gloria. Una estética teológica. Madrid: editorial Encuentro, 7 vols.

Barry, Peter (1995). Beginning Theory. Manchester: Manchester University Press.

Black, Edwin (1978). Rhetorical Criticism. Madison: University of Wisconsin Press.

Bloom, Harold (2005). ¿Dónde se encuentra la sabiduría? Madrid: Taurus.

Bloom, Harold (2011). Anatomía de la influencia. La literatura como modo de vida. Madrid: Taurus.

Booth, Wayne (2005). Las compañias que elegimos. Una ética de la ficción. México: Fondo de Cultura Económica.

Catelli, Nora (1991). El espacio autobiográfico. Barcelona: Lumen.

Cioranescu, Alejandro (2014). «Tercera articulación: la literatura», en La forma del tiempo. Ensayos de literatura general y comparada. Madrid: Biblioteca Nueva, pp. 49-72.

Compagnon, Antoine (2007). Los antimodernos. Barcelona: Acantilado.

Compagnon, Antoine (2015). El demonio de la teoría. Literatura y sentido común. Barcelona: Acantilado.

Culler, Jonathan (2007). The Literary in Theory. Stanford: Stanford University Press.

Dauzat, Pierre-Emmanuele (comp.) (2003). Steiner. París: editions de L'Herne.

Dijk, Teum van (comp.) (2000). El discurso como estructura y proceso. Estudios sobre el discurso: Una introducción multidisciplinaria I-II. Barcelona: Gedisa.

Eagleton, Terry (1999). La función de la crítica. Barcelona: Paidós.

Eagleton, Terry (2005). Después de la teoría. Barcelona: Debate.

Eagleton, Terry (2012). Figuras de disenso. Ensayos críticos sobre Fish, Spivak, Žižek y otros autores. Buenos Aires: Prometeo.

Ferraris, Mauricio (2013). Manifiesto del nuevo realismo. Madrid: Biblioteca Nueva.

Frye, Northrop (1977). Anatomía de la crítica. Caracas: Monte Ávila editores.

García Berrio, Antonio (2008a) [1977]. «Crítica formal y función crítica», en El centro en lo múltiple (Selección de ensayos) I Las formas del contenido (1965-1985). Barcelona: Anthropos, pp. 412-432.

García Berrio, Antonio (2008b) [1984]. «Más allá de los "ismos": sobre la imprescindible globalidad crítica», en El centro en lo múltiple (Selección de ensayos) I Las formas del contenido (1965-1985). Barcelona, Anthropos, pp. 641-678.

García Berrio, Antonio (2009a) [1992]. «Escepticismo e hipercriticismo (Popularidad y límites de Presencias reales)», en El centro en lo múltiple (Selección de ensayos) II El contenido de las formas (1985-2005). Barcelona: Anthropos, pp. 684-690. 
García Berrio, Antonio (2009b) [2001]. «Grandeza y servidumbres del ensayo contemporáneo: Steiner», en El centro en lo múltiple (Selección de ensayos) II El contenido de las formas (1985-2005). Barcelona: Anthropos, pp. 691-697.

Garrido Gallardo, Miguel Ángel (2004). Nueva introducción a la Teoría de la Literatura. Madrid: Síntesis.

González Alcázar, Felipe (2005). Procesos de la poética clasicista. Murcia: Universidad de Murcia.

González Alcázar, Felipe (2008). «La teoría de la literatura hoy: aproximación desde el ámbito español», Cálamo. 52, pp. 36-42.

González Alcázar, Felipe (2010). «Ortega ante la verdad poética», Revista de Occidente. 353, pp. 125-138.

Jauss, Hans-Robert (2012). Caminos de la comprensión. Madrid: Antonio Machado Editores.

Krieger, Murray (1992). Teoría de la crítica. El sistema de una tradición. Madrid: Visor.

Lentricchia, Frank (1990). Después de la «Nueva Crítica». Madrid: Visor.

Ortega y Gasset, José (2006). Obras completas 1941-1955. Madrid: Taurus, Fundación José Ortega y Gasset, tomo VI.

Poulet, Georges (comp.) (1969). Los caminos de la crítica. Barcelona: Planeta.

Rancière, Jacques (2009). La palabra muda. Ensayo sobre las contradicciones de la literatura. Buenos Aires: Eterna Cadencia Editora.

Schaeffer, Jean-Marie (2013). Pequeña ecología de los estudios literarios. ¿Por qué y cómo estudiar la literatura? Buenos Aires: Fondo de Cultura Económica.

Steiner, George (1982) [1973]. Lenguaje y silencio. Ensayos sobre la literatura, el lenguaje y lo inhumano. Barcelona: Gedisa.

Steiner, George (1990) [1984]. Lecturas, obsesiones y otros ensayos. Madrid: Alianza Editorial.

Steiner, George (1996) [1990]. Antígonas. La travesía de un mito universal por la historia de Occidente. Barcelona: Gedisa.

Steiner, George (1997) [1996]. Pasión intacta. Madrid: Siruela.

Steiner, George (1998a) [1989]. Presencias reales. ¿Hay algo en lo que decimos? Barcelona: Destino.

Steiner, George (1998b) [1971]. En el castillo de Barba Azul. Aproximación a un nuevo concepto de cultura. Barcelona: Gedisa.

Steiner, George (1999) [1978, 1989]. Heidegger. México: Fondo de Cultura Económica.

Steiner, George (2001a) [1974]. Nostalgia del Absoluto. Madrid: Siruela.

Steiner, George (2001b) [1990]. Gramáticas de la creación. Madrid: Siruela.

Steiner, George (2001c) [1978]. Sobre la dificultad y otros ensayos. México: Fondo de Cultura Económica.

Steiner, George (2001d) [1975, 1992]. Después de Babel. Aspectos del lenguaje y de la traducción. México: Fondo de Cultura Económica.

Steiner, George (2001e) [1961]. La muerte de la tragedia. Barcelona: Azul.

Steiner, George (2002) [1977]. Extraterritorial. Ensayos sobre literatura y la revolución lingüistica. Madrid: Siruela.

Steiner, George (2004) [2003]. Lecciones de los Maestros. Madrid: Siruela.

Steiner, George (2006) [2003]. Los logócratas. Madrid: Siruela.

Steiner, George (2008). Los libros que nunca he escrito. Madrid: Siruela.

Steiner, George (2009). George Steiner en «The New Yorker». Madrid: Siruela.

Steiner, George (2011) [1997]. Errata. El examen de una vida. Barcelona: Siruela-Debolsillo. 
Steiner, George (2012) [2011]. La Poesía del pensamiento. Del helenismo a Celan. Madrid: Siruela.

Todorov, Tzvetan (2005). Crítica de la crítica. Barcelona: Paidós.

Whanón Bensusán, Sultana (2008). «Pensar la literatura», en Teoría de la literatura y de la interpretación literaria. Ensayos y reflexiones. Vigo: Academia del Hispanismo, pp. 259-269.

Fecha de recepción: 21 de marzo de 2016

Fecha de aceptación: 22 de febrero de 2017 